\title{
Requirements for a virtual environment to support the social participation education of low-literates
}

\author{
Dylan G. M. Schouten ${ }^{1} \cdot$ Nanja J. J. M. Smets ${ }^{2}$ Marianne Driessen ${ }^{3}$. \\ Knup Fuhri $^{3}$ - Mark A. Neerincx ${ }^{1,2}$ - Anita H. M. Cremers ${ }^{2}$
}

Published online: 8 November 2016

(c) The Author(s) 2016. This article is published with open access at Springerlink.com

\begin{abstract}
People of low literacy experience difficulties while participating in society. Learning support software could help alleviate these difficulties. However, there is currently no overview of theoretically and empirically sound requirements for this kind of support. This paper uses the situated cognitive engineering method to create a requirements baseline for a virtual environment to support the societal participation education of low-literates (VESSEL), based on an analysis of the domain, human factors, and current applications. Four major outcomes are presented. First, a comprehensive overview is collected of the operational demands and human factors knowledge relevant to societal participation learning for low-literate citizens. Second, this overview is translated into a list of eight functional requirements: focused on low-literate learners, set in the context of societal participation, and supported by claims of cognitive, affective, and social benefits to learning. Third, a sample of Dutch societal participation learning support programs is assessed using these requirements, to highlight both current technology best practices and discrepancies between theory and practice. Fourth, virtual learning environment technology is suggested as an 'enabling' technology; an overview is shown of how virtual environments, actors, and objects can beneficially enable meeting the requirements baseline. Finally, directions for future study are discussed.
\end{abstract}

Dylan G. M. Schouten

dylan.schouten@gmail.com

1 Faculty of Electrical Engineering, Mathematics and Computer Science, TU Delft, Delft, Netherlands

2 TNO, Soesterberg, Netherlands

3 CINOP, Den Bosch, Netherlands
Keywords Societal participation · Low literacy · Virtual learning environment $\cdot$ Situated cognitive engineering

\section{Introduction}

In the Netherlands, societal participation is difficult for low-literate citizens, i.e. people dealing with issues stemming from insufficient reading, writing, speaking, and language comprehension skills. De Greef [28] defines societal participation as acting in a society to achieve certain goals. This makes it a socio-behavioural aspect of social inclusion, which is the state of 'being able to take part in society' [114]. Example domains of societal participation include: social interaction with other members of society and formal institutions, societal obligations, selfdirected learning and development, and economical and political engagement. Low degrees of participation are associated with unemployment, low socio-economic status, and social isolation [48, 87].

Participating in a modern information society requires that citizens possess the knowledge and the information and communication skills needed to find their own way in society, or know where to go for help [76, 110]. Information and communication technology (ICT) skills are increasingly a participation requirement [81]. Because lowliterate people have limited language comprehension and communication skills, they are impeded from this. Specific examples of behaviours hindered by low literacy include finding work, explaining health concerns to a doctor, socially interacting with peers and neighbours, and using computers and ICT effectively [16, 28, 29, 77].

Three common dimensions of societal participation issues can be seen: cognitive, affective, and social. Cognitive components include the lack of skills, practical 
knowledge, and experience needed for effective participation. Affective components encompass limited self-efficacy with regard to participation, and feelings of fear, shame, frustration, and stress [77, 109]. Social components consist of relationships with peers, teachers, and other actors. When these relationships are unsupportive, motivation is limited and learning is impeded [28, 30]. Improving the societal participation of low-literate citizens requires learning support that is fine-tuned towards the individual learner's cognitive, affective, and social learning preferences. This can be done, respectively: by connecting learning content to specific problem areas and desired skills, by focusing on the learner's emotional experience, motivation, and self-efficacy, and by forming meaningful connections between learners and the social learning environment.

A range of learning support programs aimed at this area already exists. These programs focus on three topics: 'language learning' trains vocabulary, 'participation skill development' train the behaviours needed to participate, and 'knowledge of Dutch society' trains Dutch social norms and rules. Training these areas has been shown to significantly improve societal participation behaviour levels [30]. Methods such as classroom lessons, roleplaying exercises, book learning, and educational software are used for this training. However, these methods have cognitive, affective, and social drawbacks. Cognitively, lesson plans and materials aimed at larger learner groups are difficult to individualize; this prohibits connecting them to learner skills and interests. Affectively, classroom attendance is difficult for low-literate learners [16] as emotional 'barriers of going to class' can be significant. Socially, mass-produced teaching material can only poorly incorporate the learners' real-life contexts into the learning process. These areas represent room for improvement in the field of societal participation learning support.

Virtual learning environment (VLE) software could provide this contextualized, situated learning support. Virtual environments combine (1) computer-generated spaces and environments, (2) digital actors and characters, and (3) virtual objects and artefacts [11]. Particularly interesting is the fact that VLEs '...offer the opportunity to simulate a realistic and safe environment for learners to perform specific tasks' [50: 1171]. A realistic VLE designed around societal participation behaviour could help low-literate people in several ways. Cognitively, VLEs provide many data visualization options [79], allowing learner skills and limitations to be taken into account more easily. Affectively, the safe and personal nature of VLE learning can reduce the factors of shame and fear of social judgement, eliminating the aforementioned barrier of 'going to class'. Socially, VLEs foster social presence and interaction between students, facilitating group discussion and teamwork and supporting the formation of meaningful social connections. These factors can all engage reticent learners in the learning process.

Supporting the societal participation learning of lowliterate citizens through VLE design is the aim of the COMMIT project 'Interaction for Universal Access' [53]. COMMIT is an ICT-focused research program where researchers, developers, and consultants investigate how ICT can be used to help low-literate citizens learn about and improve their societal participation. A multidisciplinary approach ensures that all relevant demographic, didactical, and technological angles are taken into account. By acquiring the necessary requirements, and developing the models, methods, and prototypes needed for description and experimental evaluation, the project intends to create a comprehensive specification of the envisioned learning support system 'Virtual Environment to Support the Societal Participation Education of Low-Literates', or VESSEL.

To achieve this, this study uses the situated cognitive engineering (sCE) method [82]. This method integrates human factors and technology drivers into an iterative ICT design and development process. The sCE method has three phases. In the foundation phase, relevant operational demands, human factors knowledge, and technology are collected into a strong theoretical basis for the design process. In the specification phase, these foundation data are used to derive functional requirements. These requirements are contextualized by use cases and scenarios, and justified by verifiable claims. Finally, in the evaluation phase, these specification requirements and claims are evaluated. Figure 1 shows a simplified schematic overview

\begin{tabular}{|c|c|c|}
\hline \multicolumn{2}{|c|}{ Specification } & Evaluation \\
\hline Requirements & Claims & $\begin{array}{l}\text { Technology } \\
\text { Assessment }\end{array}$ \\
\hline \multicolumn{3}{|c|}{ Foundation } \\
\hline $\begin{array}{l}\text { Operational } \\
\text { Demands }\end{array}$ & $\begin{array}{l}\text { Human Factors } \\
\text { Knowledge }\end{array}$ & Technology \\
\hline $\begin{array}{c}\text { Actors } \\
\text { Environment } \\
\text { Task }\end{array}$ & $\begin{array}{c}\text { Adult learning } \\
\text { theory } \\
\text { Computer-supported } \\
\text { learning principles }\end{array}$ & $\begin{array}{l}\text { Current } \\
\text { technology } \\
\text { Enabling } \\
\text { technology }\end{array}$ \\
\hline
\end{tabular}

Fig. 1 Situated cognitive engineering method phases: the foundation phase (lower box), the specification phase (top left box), and the evaluation phase (top right box) [82] 
of the sCE method, adapted to highlight the focus of this study.

Currently, there is no clear overview of the requirements that VLE software aimed at low-literates should adhere to. This study aims to address this in four ways. First, literature study and domain analysis are used to create a comprehensive overview of the operational demands and human factors knowledge elements of the sCE foundation. Operational demands form a structured overview of the context of use of the envisioned software [54]: the actor demographics of low-literate learners, a description of 'societal participation behaviour', and the cognitive, affective, and social processes important to the task of societal participation learning. Human factors knowledge presents insight into adult learning theory and principles of computer-supported learning. Second, the established foundation is used to derive an initial list of functional requirements for the proposed VESSEL system. Cognitive, affective, and social claims of learning benefit are also derived. Third, a selection of existing learning support programs is assessed using the derived requirements. The goal of this assessment is to explore which requirements are and are not met in daily practice. This highlights discrepancies between theoretical and practical importance, and collects practical examples of requirements implementation. Fourth, VLE technology is proposed as a possible 'enabling' technology for meeting the VESSEL specification. Virtual environments, actors, and objects all have particular characteristics that make it easier to effectively implement most of the requirements. In this way, this study aims to answer the following questions:

1. Which attributes of the actor demographics, societal participation behaviours, learning processes, adult learning theories, and computer-supported learning principles are relevant for the design of VESSEL?

2. How can these attributes be used to adapt learning support to the skills and characteristics of individual users? Which functional requirements and claims can be derived?

3. Which of these functional requirements are met by current learning support programs? Which ones are not? What lessons can be learned from this?

4. How can these requirements and lessons be used in the design of VESSEL? How can the use of virtual environment technology help with this?

The structure of this paper is as follows. Section 2 forms the operational demands part of the sCE foundation, describing the actor demographic of low-literate people, defining the conceptual environment of 'societal participation behaviour', and providing insight into the cognitive, affective, and social processes underlying the core task of learning. Section 3 forms the human factors knowledge part, investigating frameworks of adult education and ICT learning principles. Section 4 makes use of the current foundation to derive a specification for VESSEL: a list of functional requirements and claims. Section 5 forms the technology part, respectively listing examples of current societal participation learning support programs, assessing these programs on the basis of the functional requirements, and expanding on the unique attributes of virtual environment software. Section 6 forms the conclusion.

\section{Operational demands}

Operational demands comprise three main categories: actors, environment, and task (i.e. what user group will the design be aimed at, what environment will be the design used in, and what task is the design intended for). First, the actor demographic of 'low-literate Dutch people' is explored, and further defined in terms of learner profiles. Second, the environment in which societal participation takes place is described. Third, the task of societal participation learning is defined by describing the cognitive, affective, and social processes involved.

\subsection{Actors: low-literate citizens}

This section describes the actor demographic of low-literate Dutch citizens. After defining the concept of 'low literacy' in functional terms, the corresponding demographic information is presented. Building on this, five 'learner profiles' are introduced, and their relevance to software design is explained.

\subsubsection{Literacy}

Buisman and Houtkoop [16] use results from the 2012 Programme for International Assessment of Adult Competencies to define the core skills of societal participation. These core skills include literacy, mathematics ability, and general problem solving. Literacy is the ability to comprehend, process, and make use of information. The Organization for Economic Co-operation and Development (OECD) defines literacy as 'the ability to understand and employ printed information in daily activities, at home, at work and in the community - to achieve one's goals, and to develop one's knowledge and potential' [84: X]. Literacy is an important determinant for successful societal participation, particularly in modern information societies $[37,81]$. Anyone whose mastery of this core skill is too low to allow them to act and live as an independent citizen is considered low-literate. 


\subsubsection{Demographic information}

Currently, about 1.3 million people between the ages of 16 and 65 living in the Netherlands are low-literate [29]. This works out to around $10 \%$ of the labour force. This percentage has remained stable for the past two decades, and is projected to persist until at least 2020 [49]. The collection of people of low literacy living in the Netherlands is not homogeneous. Based on language background, two broad groups have been defined: 'NT1' and 'NT2'. 'NT1' refers to native Dutch people of low literacy, who are said to be learning 'Dutch as a first language'. 'NT2' refers to Dutch citizens with a non-Dutch mother tongue, who are said to be learning 'Dutch as a second language'. Included in this second group are both low-educated first-generation migrant citizens, who are functionally low-literate in both their mother tongue and in Dutch, and second-generation migrants for whom Dutch is not a mother tongue, and who have often seen little writing in their upbringing. Crucially, this group does not contain migrant citizens who are functionally literate in their mother tongue though not in Dutch, as their particular issues fall in the field of second language acquisition.

In theory, the two groups are different enough in skills, problems, and context to merit individual study. In practice, demographic studies report large overlaps in terms of literacy-related issues. While significant differences between the experiences of NT1 and NT2 learners exist, the shared issue of low literacy suggests strong, meaningful commonalities in problem areas, solution directions, and support possibilities. As such, the term 'low-literate' is used here to encompass all literacy-impaired citizens of the Netherlands, regardless of background.

De Greef et al. [29] further describe this demographic. Low literacy increases with age: while only $5 \%$ of citizens aged 16-24 is low-literate, $21.5 \%$ of citizens aged 55-65 is. Education levels among low-literates tend to be low, with as many as $42 \%$ not surpassing primary school levels. Low literacy affects men and women almost equally. Finally, roughly two-thirds of low-literates are native citizens, with the rest splitting over first- and second-generation migrants. These statistics provide design and study guidelines: lowliterate citizens are likely to be older men and women, more often native than non-native, and poorly educated.

Low-literates are less likely to work with computers and technology than people of higher literacy. This suggests a possible 'digital gap': a divide between the high-literate people capable of working with modern computer technology, and the low-literate people incapable of doing so $[14,35]$. This would have negative repercussions for using software to provide learning support. However, these fears may be unfounded. Houtkoop et al. [49] report relatively high technology usage statistics among Dutch low-literate citizens. Nine out of ten low-literates have home access to a personal computer, and access to the internet. Three quarters of low-literates have some significant computer experience, and almost half regularly use a computer at work. In the Netherlands, only one in five low-literates is seriously lacking in computer skills [29]. Furthermore, significant numbers of Dutch low-literates exhibit personal interest in computer skills learning, and they expect that computer skills learning will become relevant to their situation in the near future [49]. Correspondingly, while care is still needed, there is no indication that learning support software would be significantly less effective for the majority of low-literate learners than it would be for literate learners.

\subsubsection{Learner profiles}

Based on studies of language learning class attendants, Kurvers et al. [69] have derived five low-literate learner profiles. These profiles divide the low-literate demographic in strata. This is based on language background, educational history, current literacy level (based on the Common European Framework of Reference for Languages, cf. [111]), needed improvements, and potential complicating factors. The five profiles are detailed in Table 1.

The learner profiles listed in Table 1 are useful for study and software design, for example in classification and prediction. Not all learner profiles are equally interesting in the context of societal participation software design. For both profiles 1 and 5, a software-based solution seems relatively ineffective. Learners in profile 1 are at a high enough level of skill and self-direction that software learning support will not provide much benefit. The 'difficult' learners in profile 5 are too low-skilled and literacydeficient for a computer-based solution to be functionally applicable. Profiles 2, 3, and 4 could still benefit from societal participation learning support. Consequently, these three profiles are used throughout the design process.

\subsection{Environment: societal participation behaviour}

As noted by de Greef [28] and Schouten [96], societal participation is expressed through the goal-directed social behaviours of citizens. Societal participation is behaviour. Similarly, 'improving societal participation' can be understood to mean 'learning to better perform goal-directed social behaviours in a societal context'.

The three key elements of societal participation behaviour are language, societal knowledge, and participation skills. The 'language' aspect refers to the ability to effectively communicate in and participate in modern society. According to Breen and Candlin [13], language learning involves '...learning how to communicate as a member of 
Table 1 Low-literate learner profiles

\begin{tabular}{|c|c|c|c|c|c|}
\hline Profiles & $\begin{array}{l}\text { Language } \\
\text { background }\end{array}$ & Educational history & Current literacy levels & Complications & $\begin{array}{l}\text { Needed } \\
\text { improvements }\end{array}$ \\
\hline $\begin{array}{l}\text { Profile 1: The } \\
\text { advanced } \\
\text { learner }\end{array}$ & $\begin{array}{l}57 \% \text { NT1 } \\
43 \% \text { NT2 }\end{array}$ & $\begin{array}{l}9 \text { years of formal } \\
\text { schooling on average } \\
70 \% \text { regular schooling } \\
30 \% \text { special schooling }\end{array}$ & $\begin{array}{l}\text { Reading: } \mathrm{A} 2 \text { to } \mathrm{B} 1 \\
\text { Writing: } \mathrm{A} 2 \text { to } \mathrm{B} 1 \\
\text { Speaking: } \mathrm{B} 1\end{array}$ & - & Writing \\
\hline $\begin{array}{l}\text { Profile 2: The } \\
\text { average learner }\end{array}$ & $\begin{array}{l}57 \% \text { NT1 } \\
43 \% \text { NT2 }\end{array}$ & $\begin{array}{l}9 \text { years of formal } \\
\text { schooling on average } \\
70 \% \text { regular schooling } \\
30 \% \text { special schooling }\end{array}$ & $\begin{array}{l}\text { Reading: A2 } \\
\text { Writing: A2 } \\
\text { Speaking: A2 }\end{array}$ & - & $\begin{array}{l}\text { Reading, writing, } \\
\text { occasionally } \\
\text { speaking }\end{array}$ \\
\hline $\begin{array}{l}\text { Profile 3: The } \\
\text { non-native } \\
\text { learner }\end{array}$ & $\begin{array}{l}0 \% \text { NT1 } \\
100 \% \text { NT2 }\end{array}$ & $\begin{array}{l}9 \text { years of formal } \\
\text { schooling on average } \\
70 \% \text { regular schooling } \\
30 \% \text { special schooling }\end{array}$ & $\begin{array}{l}\text { Reading: } \mathrm{A} 2 \text { to } \mathrm{B} 1 \\
\text { Writing: } \mathrm{A} 2 \text { to } \mathrm{B} 1 \\
\text { Speaking: } \mathrm{A} 1 \text { to } \mathrm{B} 1\end{array}$ & $\begin{array}{l}\text { Possess limited } \\
\text { vocabulary, which } \\
\text { limits reading, writing, } \\
\text { and speaking. }\end{array}$ & $\begin{array}{l}\text { Speaking skill and } \\
\text { vocabulary }\end{array}$ \\
\hline $\begin{array}{l}\text { Profile 4: The } \\
\text { low-skilled } \\
\text { native Dutch } \\
\text { learner }\end{array}$ & $\begin{array}{l}100 \% \text { NT1 } \\
0 \% \text { NT2 }\end{array}$ & $\begin{array}{l}\text { Almost entirely special } \\
\text { schooling. Indeterminate } \\
\text { length }\end{array}$ & $\begin{array}{l}\text { Reading: } \mathrm{A} 1 \text { to } \mathrm{A} 2 \\
\text { Writing: } \mathrm{A} 1 \text { to } \mathrm{A} 2 \\
\text { Speaking: } \mathrm{C} 1 \text { (native) }\end{array}$ & $\begin{array}{l}\text { Dyslexia is either } \\
\text { suspected or } \\
\text { confirmed in most of } \\
\text { these learners. }\end{array}$ & $\begin{array}{l}\text { Reading, writing, } \\
\text { functional } \\
\text { literacy }\end{array}$ \\
\hline $\begin{array}{l}\text { Profile 5: The } \\
\text { difficult learner }\end{array}$ & $\begin{array}{l}\text { Unspecified } \\
\text { mix of NT1 } \\
\text { and NT2 }\end{array}$ & Unspecified. Very little & $\begin{array}{l}\text { Reading: A1 or below } \\
\text { Writing: A1 or below } \\
\text { Speaking: A1 or below }\end{array}$ & $\begin{array}{l}\text { Little to no skill at } \\
\text { learning: learning } \\
\text { disabilities suspected, } \\
\text { very limited } \\
\text { schooling. }\end{array}$ & $\begin{array}{l}\text { Dependent on } \\
\text { individual } \\
\text { circumstances }\end{array}$ \\
\hline
\end{tabular}

Columns, from left to right: Profile description, NT1/NT2 distribution, average educational, learner literacy levels (using CEFR levels), additional common complications, commonly needed improvements. Data from [69]

a particular socio-cultural group' [13: 90]. Particularly for low-literate second language learners, limited vocabulary is a major participation impediment [69]. The 'societal knowledge' aspect indicates knowledge of how to act in society. Low-literate second language learners often follow cultural norms and assumed rules, which may be spread around by word of mouth and experience, instead of formal written rules. For native low-literate learners, problems occur in situations where the required information and communication skills are too complex. Finally, the 'participation skills' aspect describes the functional skills needed to be successful at participation behaviour.

Schouten [96] has created a model that uses the dimensions of skill and context to map out the societal participation behaviour domain (see Fig. 2). In this model, the skill dimension ranks behaviour on varying degrees of information skill (the ability to comprehend and process information) and/or communication skill (the ability to communicate with others). The context dimension describes the kind of social setting the societal participation behaviour takes place in: either more formal, characterized by rigid structures and a less personal atmosphere, or more informal, characterized by a less imposing and more openended nature. Figure 2 also shows examples of societal participation behaviours that low-literate citizens have been found to struggle with.

\subsection{Task: societal participation learning}

This section expands on the task of learning, which makes up the core of 'societal participation learning'. Three categories of processes that influence the effectiveness of the learning process have been defined: cognitive processes, affective or emotional processes, and social processes (cf. [51]).

\subsubsection{Cognitive processes}

Cognitive processes refer to those processes that influence the rational, cognitive relation between learner and learning. Cognitive processes involve elements such as reading and writing skill, memory, domain-specific knowledge, learning aptitude, prior experience, and task difficulty. The influence that cognitive and meta-cognitive strategies such as scaffolding (cf. [106]), planning, organizing, and monitoring have on learning effectiveness and academic outcome is well documented [19, 39, 74]. Cognitive processes regulate the balance between learning difficulty and learner skill, forming a strong determinant for learning success [90]. Transfer of learning, the degree to which the learned material transfers to the learner's daily life, is a particularly important cognitive measure of learning effectiveness 


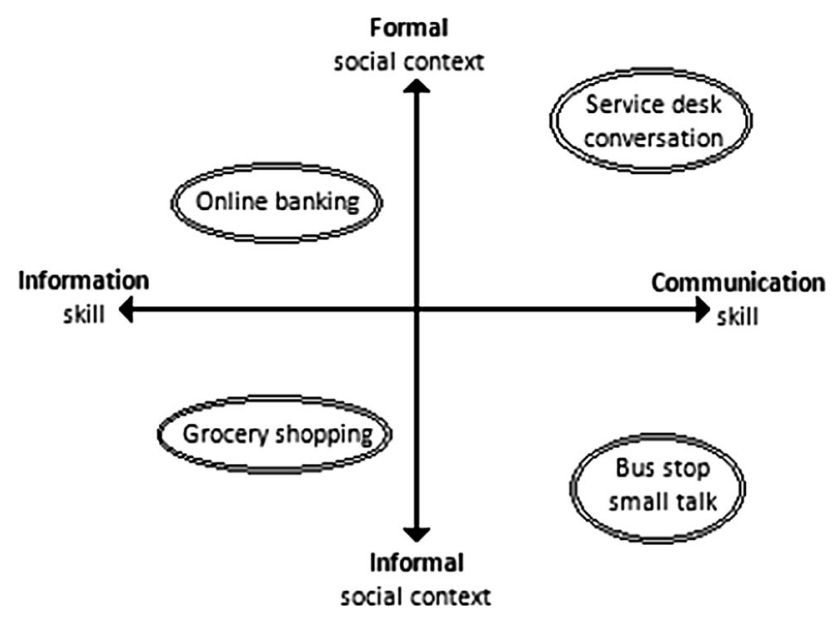

Fig. 2 Societal participation behaviour model. Based on [95]

$[28,90]$, especially in behaviour-oriented domains such as societal participation.

\subsubsection{Affective processes}

Affective processes refer to those processes that influence the affective, emotional relation between learner and learning. Affective processes involve the learners' emotional state, their self-image as a capable learner, and their feelings about the learning process. The important role of affective processes can be understood by looking at selfefficacy. First described by Bandura [4, 5], self-efficacy refers to an individual's task-specific judgment of their own capabilities. In a wide range of fields, self-efficacy is a powerful predictor of behavioural intent, motivation, and performance. These fields include academic achievement [6, 85, 99-101], reading and writing [102], computer use and adoption in general [14, 35], and computer use specifically for learning $[1,55]$. Low self-efficacy is a significant factor in explaining the low societal participation of low-literate citizens. Van Linden and Cremers [109] and Mertens and van het Zwet [77] demonstrate the harmful nature of low 'societal participation' self-efficacy. Cremers, de Jong and van Balken [24] show the use of automated teller machines (ATMs) as a concrete example of the practical issues low self-efficacy can cause. Schouten [97] further claims that low self-efficacy with regard to learning and academic achievement inhibits learning behaviour for low-literate learners (cf. [21]), and that low self-efficacy about technology literacy and computer use impedes the effectiveness of learning support software.

Next to self-efficacy, additional affective roles are played by emotions such as fear and shame. The deleterious effect of fear on academic engagement and success is well known [6, 94]. Moreover, shame about low literacy has been shown to inhibit societal participation, learning engagement, and learning effectiveness in low-literate citizens $[17,24]$.

\subsubsection{Social processes}

Social processes refer to those processes that influence the social, environmental relation between learner and learning. Social processes relate to other humans involved in learning, such as peers and teachers, as well as to the environments in which learning and practice take place. These processes often reflect on the learner's judgement of the learning process itself: negative attitudes towards learning can often be traced back to poor formative classroom experiences (cf. [21]). In this light, motivation to act is an important social process (cf. [45]). The effects of motivation on behaviour choice and persistence [6] are well known, and motivation has been related to learning behaviour [39, 44], academic success [73], writing [112], and computer technology use [104]. The social aspect of motivation can be seen in the influence of encouragement or discouragement from social peers. Motivation to get started in the learning process has particularly strong social components: positive or negative first interaction with new teachers and learning peers can determine later learning intention, either guiding new learners into the process gently or scaring them off altogether.

Motivation to go to class is supplanted by interest in and engagement with the learning process. Interest and engagement have been linked to academic success. Facer et al. [38] show that engaged, active students are interested in the learning process, while unengaged students are passive and resistant to learning. Garcia and Pintrich [39] list personal interest and 'a sense of achieving personal goals' as a subset of academic performance predictors. Levy [72] additionally suggests that personal interest in the learning environment works as a predictor for learner retention: learners who feel satisfied with their learning environment are less likely to drop out. Both Parker [86] and Schunk [101] suggest that learner locus of control factors into retention as well. Learners who feel as if they lack choice in working on a task are less likely to keep going than learners who feel like they are in control.

\section{Human factors knowledge}

In this section, human factors knowledge relevant to the design of societal participation learning support software is presented. First, adult learning theories are investigated, in order to present an overview of the current didactical state of affairs. Adult learning theory is specifically selected because the low-literate target demographic, outlined in Sect. 2.1.2, covers the 16-65 age range. Second, computer- 
supported learning principles are investigated, in order to clarify in what ways the use of computer technology can help. This information has been collected by way of literature research and is presented in the following sections.

\subsection{Adult learning theory}

To date, there is no single unifying theory of adult education. A range of theories observes adult education from different perspectives and reaches different conclusions and recommendations (e.g. research on learning styles and preferences (cf. [22, 66])). Three didactical method frameworks seem particularly interesting: andragogy, transformative learning, and constructivism [40, 74-76].

Andragogy postulates that adult learners possess several characteristics, developed during adolescence or adulthood, that explain why adults learn in ways significantly different from children [63, 64]. Six learner characteristics have been identified [65]: adults are self-directed learners, driven by real-life problems, internal motivations, and societal roles and demands, who want to know why they should learn anything they are told to learn and possess accumulated life experience to draw on. These characteristics seem to offer clear and simple guidelines for adult education (however, see [21] for a rebuttal). Andragogy is interesting for the notion that not all learners have similar learning styles and preferences. Because of significant differences between low-literate individuals and between learner groups, societal participation learning should never be offered in one singular way. Successful societal participation learning support must be adjustable and adaptable to individual needs and preferences, in order to take into account different learning styles and preferences, skill levels, and difficulty curves.

Transformative learning is a type of learning that involves altering frames of reference. Mezirow [78] describes transformative learning as '.. the process by which we transform our taken-for-granted frames of reference' [78: 7]. Illeris [52] contrasts transformative learning with assimilative learning (which keeps frames of reference intact) and accommodative learning (which involves restructuring frames of reference). Rather than dealing with knowledge acquisition, transformative learning is about the learner evaluating and changing their views and assumptions on the world. The transformative learning viewpoint is valuable for highlighting the importance of a careful, sensitive approach. Societal participation learning support needs to recognize the volatility and negative affect associated with societal participation learning, and attempt to employ sensitivity to defuse or prevent it. Examples of sensitivity include: using non-confrontational language and learning examples, respecting users' desire for privacy and anonymity, and demonstrating situational and cultural awareness [7].
Constructivism sees 'learning' as the active construction of knowledge and meaning. Learners engage in this construction process through interaction with other learners, and with their own environment, experiences, and ideas $[9,56]$. In recent decades, the focus has partially shifted to the collaborative and social dimensions of learning. This particular view on constructivism is called social constructivism [62]. One social constructivist notion is that of authentic or situated learning, also known as situated cognition. The main concepts of situated cognition are that all learning takes place in a certain context and that the context in which knowledge is presented is as much a part of the learning as the knowledge itself. This context includes the physical location learning takes place in, the tools used and their method of use, and the social interaction with other people. Hansman [46] claims that 'The core idea in situated cognition is that learning is inherently social in nature' [46: 45]. Brown et al. [15] and Lave and Wenger [71] have emphasized the role of social interaction in learning, and investigated the potential benefits of situated cognition and situated learning. Studies have suggested that affective dimensions and emotions form an important situated element in the context of learning as well [32, 47, 76]. As societal participation behaviour is intrinsically situated, it follows that societal participation learning should also be. Because the goal of societal participation learning is to teach real, applicable knowledge, learning should be situated in an environment as close to the learners' real-life environment as possible. Societal participation learning support must be able to situate the learning process in the context of events, locations, behaviours, and actors that learners are likely to encounter in their day-to-day lives.

Another notion of social constructivism is its focus on social, collaborative learning. In the context of low-literate societal participation learning, both teacher-directed learning and peer-interaction learning have their place. Consequently, societal participation learning support should provide various methods of social interaction and collaboration in learning, in either fully digital or blended forms, and encourage the application of these possibilities in the learning process. Many existing e-learning theories and applications posit this social constructivist view of learning, where personal meaning-making and the social influences of peers and teachers shape the learning process and outcomes $[41,57,58]$. Initially referring to computerand ICT-supported distance learning and computer conferencing, e-learning now encompasses a style of learning that focuses on learner collaboration, technology-supported communication methods, and the formation of digital communities of inquiry [40]. One of the e-learning's typical features is the elimination of the classroom as the necessary physical hub for learning. Modern 
communication technology has all but eliminated distance as a critical factor, allowing learners and teachers in various locations to engage in joint learning processes. The utility and added value of face-to-face contact are still acknowledged; however [40], so-called blended approaches which mix elements of classroom learning and e-learning [42] are becoming increasingly prevalent. Steehouder and Tijssen [103] and Driessen et al. [34] report on the effectiveness of using blended learning with lowliterate learners.

In conclusion, four concepts have been identified as being important for the design of societal participation learning support: adaptability to learning styles and preferences, sensitivity, situatedness, and collaboration.

\subsection{Computer-supported learning principles}

ICT has always held promise in the field of education. However, its effectiveness seems highly contingent on proper introduction and use. According to Cuban [25], forcing ICT measures on unwilling teachers leads them to use the computer like a 'replacement typewriter'. Sansone et al. [94] report that unsupported at-home students display both lower motivation and poorer results than on-campus students. This section lists a number of ICT-related learning principles, derived and adapted from Richards' [92] topology of meaningful ICT learning activities. These principles are: the provision and dissemination of information, the possibility and facilitation of worldwide communication, the element of interactivity, and gaming principles.

Provision of information refers to the fact that ICT learning offers a wide range of media and information types. Video, audio, and written text can all be offered in conjunction. These possibilities make it easier to adapt elements of a learning application to individual learners' preferences. Low-literate learners, for example, could benefit from an implementation focusing on audio and video, from supporting material offered in multiple languages and at different language levels, and from languageand culture-specific elements such as avatar ethnicity and dress style. Societal participation learning support should adapt to the needs and wishes of the learners as much as possible; modal adaptability to individual user preferences is an important example of this. Used correctly, multimodality can remove significant barriers to entry and learning progress.

Worldwide communication is one of the cornerstones of ICT, allowing teachers and students to stay in contact beyond normal classroom hours. This opens up venues for directed, personalized support. This is vital in ICT learning: Nielson [83] reports high rates of failure in at-home language learning without proper support. Furthermore, it can be argued that the near-total dissemination of ICT use in information societies [108] has turned 'the proper usage of ICT communication tools' into an important societal participation skill in its own right. Given that low-literate citizens often possess reduced ICT skill levels, ICT-based societal participation learning support could serve a dual purpose in acquainting learners with ICT practices and behavioural norms. The findings by Nielson [83] and Driessen et al. [34] show that proper learning support is vital in societal participation learning. The use of ICT in this support seems a natural fit, as instantaneous, ubiquitous, and easily adaptable communication is one of its hallmarks. As Schouten [96] argues that poor learning experiences and dissatisfaction with the learning process form major participation hurdles for low-literate learners, societal participation learning support should make use of this ICT-related learning support to improve the learning experience wherever possible.

Interactivity links ICT learning to experiential learning [66, 67]. Barak [7] divides learning into four aspectscontextual, active, social, and reflective-and reports that the use of ICT enhances the contextual and active parts of learning. This implies that the interactivity of ICT learning applications is tied to both experiential learning and situated cognition, as adapting to different learning styles and preferences and to different contexts is easier in ICT than in more traditional teaching methods. For optimal learning results, societal participation learning support should actively involve users in the learning process. Good use of interactivity could be beneficial for low-literate societal participation learners.

Digital gaming is increasingly seen as a form of experiential learning [61, 91, 105]. Doshi [33] claims that using gaming to teach skills allows students to fit otherwise abstract concepts into their daily lives. Ke [59] suggests that educational games offer four potential benefits to learning: games are a conduit to experiential learning, games create and enhance engagement in students, they promote cooperation, and they could help students in digesting complex subject matter. Evidence supports some of these claims. Studies show that games can induce engagement and immersion [36], and flow and fiero [23]. Both Dickey [31] and Warren et al. [103] report that games can increase intrinsic motivation in players. Rieber [93] claims that students view gaming as 'play', but regular learning as 'work'. Gaming has also been shown to promote cooperation among school children [38]. Finally, Kriz [68] posits that '...gaming simulation represents a form of cooperative learning through teamwork.' [68: 506]. Gaming principles and gamification can be used to enhance the effectiveness and the affective and social experience of learning. Astell et al. [3] show that video games can be used with older adults with cognitive impairments, both to 
help them learn and to engage and entertain them. Similar expectations can be held about the use of gaming elements with low-literate learners. Games, and other forms of 'playful' learning, could also go a long way towards improving negative attitudes with regard to societal participation and learning (cf. [96]).

In conclusion, four concepts have been identified as being important for the design of societal participation learning support: multimodality, learning support, interactivity, and gaming principles.

\section{Specification: requirements}

In this section, the theory presented by the human factors knowledge and the context of use sketched by the operational demands are brought together to specify the requirements for the proposed VESSEL system. Claims that underlie these requirements are derived as well. These claims make explicit in what ways each requirement is expected to influence the cognitive, affective, and social processes related to learning. The requirements represent what learning support software should do, and the claims represent why this should be done (thus providing the design rationale). This makes up the specification stage of the sCE method [82] (see Fig. 1) and forms the specification for VESSEL. Requirements are summarized in the list below. A schematic overview is also shown in Table 3.

R1 Adaptability a societal participation learning support program should offer and support different learning styles and preferences and different difficulty levels.

- Cognitive Claim catering to different learning styles and preferences will allow individual lowliterate users to select those styles and difficulty levels that work best for them. This will match learning content and process to user experiences and aptitudes, and improve learning effectiveness over a one-approach-fits-all system.

- Affective Claim allowing individual users to indicate their own learning styles, preferences, and difficulty levels provides the user with a modicum of power and influence over their own learning experience. This will result in a more positive user experience.

R2 Sensitivity a societal participation learning support program should use non-confrontational language and content, demonstrate cultural awareness, and take existing emotional issues with regard to literacy and societal participation into account.

- Affective Claim demonstrating awareness of individual problems and difficulties, and showing a willingness to take these elements into account in the learning process will give users a sense of being respected and of being listened to. This will result in a more positive user experience.

- Social Claim learners who experience that their individual problems and difficulties are being respected by teachers, peers, and learning materials will be more likely to continue learning. This will improve learner retention.

R3 Situatedness a societal participation learning support program should use learning materials and contexts that are closely related to the learner's physical environment and real-life experiences.

- Cognitive Claim situating learning and support in the context of real-life situations will help in transferring useful, applicable skills and experiences. This match between user experiences and presented learning experiences will improve transfer of learning.

- Affective Claim particularly for those low-literate learners with low learning self-efficacy, placing the learning content in a well-known personal context will reduce barriers of fear and uncertainty.

- Social Claim the use of recognizable environments, actors, and skills makes learning more engaging and immersive for learners. This will improve learner retention.

R4 Collaboration a societal participation learning support program should have systems in place that enable, support, and foster social interaction and collaboration in learning.

- Cognitive Claim learning about societal participation in a social and collaborative setting will create scenarios and produce knowledge and experience that are more closely applicable to real-life participation. This will enhance learning applicability and transfer of learning.

- Social Claim the presence of peers and teacher support mixed with the privacy and safety of technology-supported learning will reduce the barriers low-literate learners experience in starting with and persisting in learning endeavours. This will improve motivation to start learning and learner retention.

R5 Multimodality a societal participation learning support program should employ multimodality, offering content in multiple concurrent ways.

- Cognitive Claim given that reading is a particular difficulty for low-literates, using presentation 
modalities other than text is preferred. However, differences between low-literates make any monolithic approach untenable. Engaging multiple modalities ensures that all low-literate learners have some preferred way of accessing learning. This will improve learning effectiveness over a system that does not use multimodality.

- Affective Claim self-conscious low-literate learners are often worried that reading skill will be required to participate in learning. Knowing that materials are offered in some other format than written text alleviates this fear, removing a significant barrier of stress and anticipation for these learners.

R6 Support a societal participation learning support program should possess built-in support options.

- Cognitive Claim good support options will aid users in understanding the learning material better. This will improve learning comprehension and effectiveness.

- Affective Claim low-literate learners value the idea of being supported. A desire for individualized, personal contact with supporting experts and peers has been reported by multiple studies with various demographics (cf. [26] on video support for caregivers). Providing proper support will set users at ease while using the learning software. This will increase their self-efficacy, both with regard to societal participation and with regard to learning itself.

- Social Claim a learner who receives support when they want it or need it will feel supported. This will lead to higher learner retention: learners are more motivated to continue when they know that help is available.

R7 Interactivity a societal participation learning support program should employ real interactivity in offering content.

- Cognitive Claim interactivity in learning behaviour is almost ubiquitous at this point in time, and the educational benefits of learning-by-doing and scenario-based learning are well documented, particularly with regard to learning transfer (cf. [59, 60, 89]).

- Social Claim negative attitudes towards the learning process can often be traced back to poor prior classroom experiences. Interactive learning will help alleviate these negative attitudes, by engaging low-literate learners more in the learning process.
R8 Gaming Principles a societal participation learning support program should use elements and principles of interactive gaming.

- Affective Claim using gaming principles will mitigate the negative affective view low-literate learners tend to have about learning in general (cf. [96]). This will result in a more positive learning experience.

- Social Claim gamification is often essentially an attempt to make learning more 'fun'. Doing this will improve engagement with and immersion in learning, and foster motivation to persist.

\section{Technology}

In this section, an overview of technology relevant to the design of societal participation learning support is presented. First, the current state of technology regarding Dutch societal participation learning support programs is investigated. Examples of learning support software are collected and described. Second, these software examples are assessed on the basis of the VESSEL requirements drafted in Sect. 4. This assessment intends to highlight which requirements are commonly met in current practice and which ones are not. Third, the enabling role of VLE technology is described. An overview is presented of how the core VLE attributes 'environments', 'actors', and 'objects' enable and support the effective implementation of many of the VESSEL requirements.

\subsection{Current technology}

In this section, an overview is shown of currently existing learning support software programs that aim to improve the societal participation of low-literate learners. This overview was created by searching for software that adheres to three characteristics. First, the software must be intended to offer learning to students about the topic at hand. Second, the software must be intended for use by low-literate learners. Third, the subject matter of the software must be societal participation learning. This means that it must focus on language acquisition, societal participation skills, and/or knowledge of Dutch society.

Six software packages met these characteristics. These packages were all integration training courses, aimed primarily at low-literate second language learners. One package also included material for native low-literate language learners. No packages that focused only on native low-literate language learners were found. None were stand-alone products. Rather, each software example was 
Table 2 Mapping of the eight requirements on current societal participation learning support software packages: For each software package, each row shows adherence to the listed requirement

\begin{tabular}{|c|c|c|c|c|c|c|}
\hline & EHBN & ETV.nl & Naar Nederland & Thuis in Nederlands & IJsbreker Plus & NL247 \\
\hline 1. Adaptability & & & $\mathrm{X}$ & $\mathrm{X}$ & $\mathrm{X}$ & $\mathrm{X}$ \\
\hline 2. Sensitivity & $\mathrm{X}$ & $\mathrm{X}$ & $\mathrm{X}$ & $\mathrm{X}$ & $\mathrm{X}$ & $\mathrm{X}$ \\
\hline 3. Situatedness & $\mathrm{X}$ & $\mathrm{X}$ & $\mathrm{X}$ & $\mathrm{X}$ & $\mathrm{X}$ & $\mathrm{X}$ \\
\hline 4. Collaboration & & & & $\mathrm{X}$ & & \\
\hline 5. Multimodality & $\mathrm{X}$ & $\mathrm{X}$ & $\mathrm{X}$ & $\mathrm{X}$ & $\mathrm{X}$ & $\mathrm{X}$ \\
\hline 6. Support & & & $X$ & $X$ & $\mathrm{X}$ & $X$ \\
\hline 7. Interactivity & $\mathrm{X}$ & $\mathrm{X}$ & $\mathrm{X}$ & $X$ & $\mathrm{X}$ & $\mathrm{X}$ \\
\hline 8. Gaming principles & & & & $\mathrm{X}$ & & \\
\hline
\end{tabular}

An X mark means the software package clearly implements the listed requirement

part of a larger integration learning programme. The software was designed to be used in concert with other materials: books, worksheets, classes, and practical exercises.

The following packages were found: EHBN, EVT.nl, Naar Nederland, Thuis in Nederlands, IJsbreker Plus, and NL247. Summaries of these software packages, including description, publisher, production year, and learning focus, have been included in appendix for purposes of study reproducibility.

\subsection{Assessment of current practice}

This section provides an assessment of the described learning software 'in isolation'. It should be noted that the software applications are part of larger, multifaceted educational programmes that are not evaluated. The interest here is in the functionality of the software only: the intent is to create an overview of which of the theory-based requirements and claims are met in current software design practice, and which ones are not. The former will provide insight into practical, effective ways of operationalizing these requirements. The latter will highlight interesting areas for future study and development.

Table 2 shows that the various requirements are reflected in software design at different levels of frequency. While the demands for sensitivity, interactivity, and multimodality are fulfilled quite often, examples of adaptability, collaboration, gamification, and support are rare.

The sensitivity (R2) requirement can be found in all evaluated examples. The implementation of sensitivity can be seen in careful word choices, and in appreciation for cultural differences. Even brief study provides many examples to emulate in future design.

As mentioned in Sect. 3, interactivity (R7) and multimodality (R5) are cornerstones of ICT technology and design. The combined cognitive benefits of ease-of-access and improved learning transfer greatly enhance learning effectiveness. And the affective benefits of lowering barriers of stress and anticipation, offered by multimodality, are almost necessary while designing for low-literate learners. Again, all software packages that were studied make good use of these possibilities: audio and video supplement text, and exercises and lessons are often interactive. Examples can be seen in IJsbreker Plus' audiosupported multiple-choice questions, in ETV.nl presenting questions both in written text and in spoken forms, and in NL247 using interactive exercises that involve situated visual aids, such as realistic-looking agendas and letters.

The situatedness requirement (R3) represents a special case. All software packages studied use a certain degree of situated content: exercises and examples are embedded in the larger goal of attempting to integrate in the Netherlands. Narrative scenarios are supported with avatar personas, designed to embody and represent the user demographics. This level of situated content represents a 'partial' form of situatedness. The material used is closer to the daily-life experiences of the users than entirely nonsituated material and thus provides the described cognitive, affective, and social learning benefits to some degree. However, it is not fully personalized and contextualized to the individual users. Educational material and content that uses real, immediately recognizable elements from the user's day-to-day life would represent a higher level of situatedness. Future studies should investigate whether or not this level of individual situatedness is practical to achieve, and if the benefits derived from doing so outweigh the additional required effort.

While learning support (R6) is seen as important and necessary in literature, practical software implementations are uncommon. As most of the software packages have not been designed as stand-alone learning methods, the learning support is assumed to come from teachers and peers, not from the program itself. While these kinds of learning support are still beneficial, digital learning support has 
potential benefits of its own. Only the IJsbreker Plus and Naar Nederland software packages explicitly offer audio support and speech recognition in different languages. NL247 possesses both a technical support help desk and an easily accessible dictionary, though it limits its contentlevel automated support to a text message functionality between learners and teachers. Uniquely, Thuis in Nederlands offers 'e-coaching' as a method of digital directcontact support. Given the beneficial claims associated with digital learning support, the relative rarity of softwarebased support should be investigated in more depth.

Learning style and preference adaptability (R1) has proved to be a difficult concept to find and operationalize in practice. IJsbreker Plus, Naar Nederland, Thuis in Nederlands, and NL247 offer adaptability personalization in the form of a range of different exercise types. The fact that other software packages mostly stick to multiple-choice questions suggest that any adaptability in these methods is found in other material. Future study could investigate if software-based adaptability has significant benefits over this existing method- and material-based adaptability, particularly where low-literate learners are concerned.

Implementations of social interaction and collaboration (R4) functionality are rare. Only Thuis in Nederlands offers e-learning functionalities and online group-based exercises. Again, many software packages primarily offer self-study exercises to supplement existing classroom work. The lack of social cooperation options built into the software packages limits their effectiveness as standalone solutions. However, more study is needed to determine whether or not mediated collaboration efforts would work well with low-literate learners to begin with.

Finally, gaming principles (R8) are equally rare, only showing up once: Thuis in Nederlands uses virtual board games and a virtual reality environment to enhance its learning experiences and engage learners. These findings represent a major departure from literature assumptions, which warrant future study. Schouten, Pfab, Cremers, van Dijk, and Neerincx [98] have already demonstrated that literature expectations regarding gaming principles and gamification might not translate to a low-literate user group.

\subsection{Enabling technology}

This section describes how VLE technology can serve as an 'enabling technology' for VESSEL. As described in Sect. 1, VLEs can contain computer-generated environments and spaces, present digital actors and characters, and possess digital objects and artefacts $[11,50]$. These attributes each provide potential benefits to fulfilling the functional requirements described in Sect. 4. Not all current VLEs use all possibilities in equal measure. For example, the Thuis In Nederlands Virtual Neighbourhood uses a virtual space and virtual characters, but does not use interactive objects. Moreover, some virtual coaching programs (cf. [10, 113]) focus solely on convincing virtual characters. For each of these three attributes, a description is given of which requirements are more easily implemented by using this technology, and why this is the case. Table 3, at the end of the section, also shows a schematic overview of this.

Environments constitute the digital 'spaces' of a VLE. These environments can be abstract or realistic depictions of existing spaces. A well-designed virtual environment is almost a prerequisite for the success of VLE-based learning [12]. The following six requirements are enabled by this functionality:

- R1. Adaptability VLE environments can provide different spaces for different kinds and levels of exercises. According to Barak [7], this adaptability is much easier to realize in ICT environments than in classrooms: digital spaces can be altered much more easily than real ones.

- R3. Situatedness Maybe the most intuitive benefit of VLE technology is the potential to deliver a level of spatial situatedness no other software is capable of reaching. Realistic task environments beneficially influence feelings of physical and social presence, situatedness, and learning transfer [50]. Strongly situated virtual environments could be especially useful for participation skills training, the application of which is lacking in current software (see appendix). In the Netherlands in particular, this would address a significant gap in the current participation learning curriculum [43, 70, 107].

- R4. Collaboration Virtual environments can provide a shared space for learners to collaborate in that is time and location independent. The Thuis in Nederlands software package is an example of this. While Johnson et al. [55] warn against the socially isolating nature of digital learning, the high social presence associated with shared virtual environments can actually facilitate the formation of peer connections.

- R5. Multimodality Virtual environments are almost inherently multimodal [79], combining visual information with text and audio.

- R7. Interactivity VLE-based learning set in realistic virtual spaces benefits from intuitive interaction possibilities [79]. Virtual spaces designed to afford realistic interaction are easy to parse even for learners with relatively little computer experience.

- R8. Gaming principles The natural interaction style and increased social interaction offered by virtual spaces [50] all enable the immersion, engagement, motivation, and attitude benefits claimed from the use of gamification in learning $[23,27,80]$. 
Table 3 Overview of (a) claimed benefits per design requirement and (b) requirement implementation benefits afforded by VLE attributes

\begin{tabular}{|c|c|c|c|c|c|c|}
\hline Requirements & Cognitive Claims & Affective Claims & Social Claims & VLE environments & VLE actors & VLE objects \\
\hline R1. Adaptability & + & + & & + & + & + \\
\hline R2. Sensitivity & & + & + & & & \\
\hline R3. Situatedness & + & + & + & + & + & + \\
\hline R4. Collaboration & + & & + & + & + & \\
\hline R5. Multimodality & + & + & & + & + & + \\
\hline R6. Support & + & + & + & & + & \\
\hline R7. Interactivity & + & & + & + & + & + \\
\hline R8. Gaming principles & & + & + & + & + & + \\
\hline
\end{tabular}

For the columns 'Cognitive Claims', 'Affective Claims', and 'Social Claims', symbol ' + ' indicates that this requirement has claims of benefit associated with this category. For the columns 'VLE environments', 'VLE actors', and 'VLE objects', symbol ' + ' indicates that this requirement benefits from this kind of VLE implementation

Actors constitute the digital 'characters' of a VLE. Actors can either be avatars, serving as digital stand-ins for users, or agents, which are autonomous software programs. The following seven requirements are enabled by this functionality:

- R1. Adaptability agents can adapt their looks and behaviour to better match user wishes and needs. Again, this is easier in a VLE than it is in a real classroom [7, 88].

- R3. Situatedness actors of any kind, either user avatars or embodied conversational agents, can add situatedness to exercises [18]. These actors can act as conversation partners, or serve as 'social background dressing', adding a layer of affective stress to social situations.

- R4. Collaboration virtual avatars can allow learners to 'see' and interact with each other remotely. Studies show that the increased social presence that results from learning with other humans, even digitally represented ones [79] is beneficial to learning effectiveness [2].

- R5. Multimodality virtual characters naturally present spoken dialogue.

- R6. Support VLE actors can serve as representations of teachers and peers, allowing users to ask for help in a natural way [8]. VLE actors can also serve as autonomous digital characters, offering structured, individualized, computer-guided support. The benefits of this learning support on success and persistence [55, 83], motivation and contentment [20], and selfefficacy [6] are well documented.

- R7. Interactivity virtual characters enable a range of scenario-specific affordances for interactivity in learning.

- R8. Gaming principles Cornelissen et al. [23] identify avatar personification and social comparison, two elements commonly associated with virtual characters, as instruments usable for tapping into flow and fiero in a gaming setting.

Objects constitute the digital 'things' of a VLE. The following five requirements are enabled by this functionality:

- R1. Adaptability the presence or absence of VLE objects can change the nature and difficulty of an exercise. An exercise can be made more complicated by the inclusion of hard-to-understand objects, or made simpler by the inclusion of objects that are easy to parse and use.

- R3. Situatedness in any given exercise environment, providing appropriate and realistic tools and other objects can improve situatedness. In exercises where 'learning to handle the object' is the goal (e.g. learning online banking), realistic objects are almost a necessity for success.

- R5. Multimodality VLE objects can present information in many ways, depending on the nature of the object: examples include digital books and newspapers for written information, or digital billboards or televisions for visual information.

- $\quad$ R7. Interactivity realistic digital objects strongly afford interactivity. ICT objects in particular can be recreated feature-perfectly in a VLE. This allows for incredibly applied practical learning.

- R8. Gaming principles VLE objects such as trophies and badges can add a layer of tangibility to gamification-related rewards.

\section{Conclusion}

This study has used the situated cognitive engineering method to create a design specification for VESSEL, a virtual environment to support the societal participation 
education of low-literate people. Analyses of the operational demands and human factors provided the foundation of the design, i.e. demographic information, societal participation models, learning processes, theories of adult learning, and computer-supported learning principles. From this foundation, a baseline of eight functional requirements and eighteen associated claims of cognitive, affective, and social learning benefit was derived. The current technology was then assessed using these requirements, in order to highlight discrepancies between literature-backed theory and the best practices of existing societal participation learning support programs. Finally, the advantages offered by VLE technology were described in terms of environments, actors, and objects.

In line with the four main research questions, this paper presents four major results. With regard to research question one 'Which attributes of the actor demographics, societal participation behaviours, learning processes, adult learning theories, and computer-supported learning principles, are relevant for the design of VESSEL?', an overview was created of the problem area of insufficient societal participation for people of low literacy. Demographic information, practice-backed learner profiles, models of societal participation behaviour, and a description of the cognitive, affective, and social processes underlying learning were used to show the operational demands associated with designing in this field.

To answer research question two 'How can these attributes be used to adapt learning support to the skills and characteristics of individual users? Which functional requirements and claims can be derived?', the operational demands overview and a human factors framework of adult learning theory and computer-supported learning principles were translated into a list of functional requirements for societal participation learning support software. These requirements, justified with theory-backed claims of cognitive, affective, and social benefits to learning, form the specification for the VESSEL system. Table 3 shows this specification.

With regard to research question three 'Which of these functional requirements are met by current learning support programs? Which ones are not? What lessons can be learned from this?', six learning support software packages, taken from Dutch integration learning programs, were assessed on the basis of these requirements. Requirements R2 (Sensitivity), R3 (Situatedness), R5 (Multimodality), and R7 (Interactivity) were found in all software packages; examples were presented of best-practice ways of implementation for these requirements. Requirements R1 (Adaptability), R4 (Collaboration), R6 (Support), and R8 (Gaming Principles) were found sparingly. This finding represents a discrepancy between theory and practice; this was highlighted in terms of the claims associated with these requirements.

Finally, to answer research question four 'How can these requirements and lessons be used in the design of VESSEL? And how can the use of virtual environment technology help with this?', an overview was created of the requirement implementation benefits of VLE technology. Table 3 shows that the use of VLE technology has significant benefits over a non-VLE system: VLE environments, actors, and objects enable many requirements to be implemented effectively. It can be concluded that VLE technology is a good technological basis for the proposed VESSEL system.

Finally, this paper offers several clear directions for future study. Results from the requirements assessment show that requirements R1 (Adaptability), R4 (Collaboration), R6 (Support), and R8 (Gaming Principles) represent areas of particular interest. While theory and literature show potential benefits in the application of these principles for VESSEL, software in current practice tells a different story. Current societal participation learning support programs do meet the requirements R2 (Sensitivity), R3 (Situatedness), R5 (Multimodality), and R7 (Interactivity) well, and offer practical examples of how to implement these in the design of VESSEL. Follow-up studies in this field should focus on verifying the practical effectiveness of the proposed VESSEL specification: the translation of existing requirement implementations into a virtual environment solution should be prototyped and tested, and the theory-practice discrepancy regarding learning support, collaboration, adaptability, and gamification should be investigated.

Acknowledgements The authors wish to acknowledge Miryam de Hoo and Jan van Erp for their valuable contributions. This publication was supported by the 'Interaction For Universal Access' track of the Dutch national program COMMIT.

Open Access This article is distributed under the terms of the Creative Commons Attribution 4.0 International License (http://crea tivecommons.org/licenses/by/4.0/), which permits unrestricted use, distribution, and reproduction in any medium, provided you give appropriate credit to the original author(s) and the source, provide a link to the Creative Commons license, and indicate if changes were made.

\section{Appendix: software overview}

Presented below is detailed information on the software packages used for assessment in Sect. 5.2. The following data are included for each entry: name, functional description, year of production, and year of cancellation (if applicable). Each entry also indicates to which of the three societal participation learning aspects in the method is 
aimed at: language, skills, and/or knowledge of Dutch society.

\section{EHBN}

EHBN (Eerste Hulp Bij Nederland, meaning 'First Aid With The Netherlands') is an older integration package that has been around since the 1990's. EHBN targets second language learners aiming for Dutch integration. Learning material consists of audio-supported multiple-choice questions. Language options are included.

Publisher: Malmberg

Year of production: 1990

Year of cancellation: 2013

Learning areas: Language, Knowledge of Dutch society

\section{ETV.nl/Oefenen.nl}

ETV.nl and Oefenen.nl ('Practice.nl') are two complementary websites that offer a large selection of learning programs. Among the programs offered are language learning segments aimed at native language learners, and integration courses aimed at second language learners. Multiple-choice questions are supported by video material.

Publisher: Expertise Foundation ETV.nl

Year of production: 2003

Year of cancellation: [still in use]

Learning areas: Language, Skills

\section{Naar Nederland}

Naar Nederland ('To The Netherlands') is described as the 'official self-study guide for the Dutch integration exam'. It targets second language learners. The method uses a DVD, several books, and online practice software. The complete package, including spoken and written segments, is offered in 18 languages. Speech recognition is also offered.

Publisher: Dutch Ministry of Social Affairs

Year of production: 2006

Year of cancellation: [still in use]

Learning areas: Language, Knowledge of Dutch society

\section{Thuis in Nederlands}

Thuis in Nederlands ('At home in Dutch') is a multimodal teaching method aimed at second language learners. It focuses on three core domains: upbringing, health care, and education. It uses a mix of classroom book learning, practical assignments, role-play, and e-learning; the latter component includes at-home work packages, a virtual 'participation board game', and a VR environment called the Virtual Neighbourhood.

Publisher: ITpreneurs

Year of production: 2008

Year of cancellation: 2014

Learning areas: Language, Skills, Knowledge of Dutch society

\section{IJsbreker Plus}

IJsbreker Plus ('Icebreaker Plus') is a language learning software package for second language learners looking for integration aid. The package combines independent online work with book exercises and classroom teaching. According to the website, the program offers a 'strong mix of learning types'. Audio-supported multiple-choice questions are used, and different language audio support is built in.

Publisher: ThiemeMeulenhoff

Year of production: 2010

Year of cancellation: [still in use]

Learning areas: Language, Knowledge of Dutch society

\section{NL247}

NL247 ('NL Twenty-four seven') was developed by the same publisher as Thuis in Nederlands, and serves as a de facto sequel. NL247 supports low-literate second language learners in a wide variety of topics derived from the latest official Dutch integration exam. Different sets of exercises focus on reading, writing, comprehension, and vocabulary; learners are encouraged to focus on those skills areas they need most. NL247's software component is complemented by classroom lessons, written materials, and practical assignments.

Publisher: ITpreneurs

Year of production: 2014

Year of cancellation: [still in use]

Learning areas: Language, Skills, Knowledge of Dutch society

\section{References}

1. Albion, P.R.: Self-efficacy beliefs as an indicator of teachers' preparedness for teaching with technology. In: Proceedings of the 10th International Conference of the Society for Information Technology and Teacher Education (SITE 1999), pp 1602-1608. Association for the Advancement of Computing in Education (AACE) (1999)

2. Annetta, L.A.: Video games in education: why they should be used and how they are being used. Theory Practice 47(3), 229-239 (2008). doi:10.1080/00405840802153940

3. Astell, A., Alm, N., Dye, R., Gowans, G., Vaughan, P., Ellis, M.: Digital video games for older adults with cognitive impairment. In: Miesenberger, K., Fels, D., Archambault, D., Penáz, P., Zagler, W. (eds.) ICCHP 2014, Part I, LNCS 8547, pp. 264-271. Springer, Paris (2014). doi:10.1007/978-3-319-08596-8

4. Bandura, A.: Self-efficacy: toward a unifying theory of behavioral change. Psychol. Rev. 84(2), 191-215 (1977)

5. Bandura, A.: Social Foundations of Thought and Action. Prentice Hall, Englewood Cliffs (1986)

6. Bandura, A.: Self-Efficacy: The Exercise of Control. http:// scholar.google.com/scholar?hl=en\&btnG=Search\&q=intitle: Self-efficacy:+The+exercise+of+control\#0 (1997) 
7. Barak, M.: Instructional principles for fostering learning with ICT: teachers' perspectives as learners and instructors. Educ. Inf. Technol. 11(2), 121-135 (2006). doi:10.1007/s11134-0067362-9

8. Baylor, A.L.: Promoting motivation with virtual agents and avatars: role of visual presence and appearance. Philos. Trans. R. Soc. Lond. B Biol. Sci. 364(1535), 3559-3565 (2009). doi:10.1098/rstb.2009.0148

9. Berger, P.L., Luckmann, T.: The social construction of reality (1966)

10. Bickmore, T., Pfeifer, L., Jack, B.W.: Taking the time to care: empowering low health literacy hospital patients with virtual nurse agents. In: CHI'09 Proceedings of the SIGCHI Conference on Human Factors in Computing Systems, pp 1265-1274 (2009)

11. Bishop, J.: The role of mediating artefacts in the design of persuasive e-learning systems. In: Proceedings of the First International Conference on Internet Technologies and Applications (ITA 05), (September), pp 54-62. http://www.jona thanbishop.mobi/Library/Documents/EN/docITA05Paper.pdf (2005)

12. Bouras, C., Giannaka, E., Tsiatsos, T.: Virtual collaboration spaces: the EVE community. In: Proceedings of the 2003 Symposium on Applications and the Internet (SAINT), pp 48-55. http://ieeexplore.ieee.org/xpls/abs_all.jsp?arnumber= 1183032 (2003)

13. Breen, M.P., Candlin, C.N.: The essentials of a communicative curriculum in language teaching. Appl. Linguist. 1(2), 89-112 (1980)

14. Broos, A., Roe, K.: The digital divide in the playstation generation: self-efficacy, locus of control and ICT adoption among adolescents. Poetics 34(4-5), 306-317 (2006). doi:10.1016/j. poetic.2006.05.002

15. Brown, J.S., Collins, A., Duguid, P.: Situated cognition and the culture of learning. Educ. Res. 18(1), 32-42 (1989)

16. Buisman, M., Houtkoop, W.: Laaggeletterdheid in kaart (2014)

17. Carvalho, M.B.: Designing for low-literacy users: a framework for analysis of user-centred design methods (2011)

18. Cassell, J., Bickmore, T.: Negotiated collusion: Modeling social language and its relationship effects in intelligent agents. User Model. User-Adap. Inter. 13, 89-132 (2003)

19. Cassidy, S.: Learning styles: an overview of theories, models, and measures. Educ. Psychol. 24(4), 419-444 (2004)

20. Chen, K.C., Jang, S.J.: Motivation in online learning: testing a model of self-determination theory. Comput. Hum. Behav. 26(4), 741-752 (2010). doi:10.1016/j.chb.2010.01.011

21. Clapper, T.C.: Beyond knowles: what those conducting simulation need to know about adult learning theory. Clin. Simul. Nurs. 6(1), e7-e14 (2010). doi:10.1016/j.ecns.2009.07.003

22. Conti, G.J.: Development of a user-friendly instrument for identifying the learning strategy preferences of adults. Teach. Teach. Educ. 25(6), 887-896 (2009). doi:10.1016/j.tate.2009.02. 024

23. Cornelissen, F., Neerincx, M.A., Smets, N.J.J.M., Breebaart, L., Dujardin, P., Wolff, M.: Gamification for astronaut training. In: The 12th International Conference on Space Operations. Stockholm, http://arc.aiaa.org/doi/pdf/10.2514/6.2012-1275405 (2012)

24. Cremers, A.H.M., de Jong, J.G.M., van Balken, J.S.: User-centered design with illiterate persons: the case of the ATM user interface. In: ICCHP 2008, LNCS 5105, pp 713-720. http://link. springer.com/chapter/10.1007/978-3-540-70540-6_104 (2008)

25. Cuban, L.: Oversold and Underused: Computers in the Classroom. Harvard University Press, Cambridge (2001)

26. Czaja, S.J., Schulz, R., Perdomo, D., Nair, S.N.: The feasability and efficacy of technology-based support groups among family caregivers of persons with Dementia. In: Miesenberger, K., Fels,
D., Archambault, D., Penáz, P., Zagler, W. (eds.) ICCHP 2014, Part I, LNCS 8547, pp. 455-458. Springer, Paris (2014). doi:10. 1007/978-3-319-08596-8

27. De Freitas, S., Liarokapis, F.: Serious games: a new paradigm for education? In: Ma, M., Oikonomou, A., Jain, L.C. (eds.) Serious Games and Edutainment Applications, pp. 9-23. Springer, London (2011). doi:10.1007/978-1-4471-2161-9

28. De Greef, M.: Leren voor leven: een eigen plek in het dagelijks leven. Velp (2009)

29. De Greef, M., Segers, M., Nijhuis, J.: Feiten \& Cijfers geletterdheid. http://www.lezenenschrijven.nl/assets/uploads/pub licaties/LS_FeitenCijfers_2.0_web_3.pdf (2014)

30. De Greef, M., Segers, M., Nijhuis, J., Lam, J.F.: Impactonderzoek taaltrajecten Taal voor het Leven door Stichting Lezen \& Schrijven op het gebied van sociale inclusie en leesvaardigheid. Maastricht (2014)

31. Dickey, M.D.: Game design and learning: a conjectural analysis of how massively multiple online role-playing games (MMORPGs) foster intrinsic motivation. Educ. Tech. Res. Dev. 55(3), 253-273 (2007). doi:10.1007/s11423-006-9004-7

32. Dirkx, J.M.: The power of feelings: emotion, imagination, and the construction of meaning in adult learning. In: New Directions for Adult and Continuing Education 89, pp 63-72. JosseyBass (2001)

33. Doshi, A.: How gaming could improve information literacy. Comput. Libr. 26(5), 14-17 (2006)

34. Driessen, M., van Emmerik, J., Fuhri, K., Nygren-Junkin, L., Spotti, M.: ICT use in L2 education for adult migrants: a qualitative study in the Netherlands and Sweden (2011)

35. Eastin, M.S., LaRose, R.: Internet self-efficacy and the psychology of the digital divide. J. Comput. Med. Commun. 6(1), 0 (2000)

36. Ermi, L., Mäyrä, F.: Fundamental components of the gameplay experience: analysing immersion. In: Proceedings of DiGRA 2005 Conference: Changing Views-Worlds in Play, p 14 (2005)

37. Eshet-alkalai, Y.: Digital literacy: A conceptual framework for survival skills in the digital era. J. Educ. Multimed. Hypermed. 13(1), 93-106 (2004)

38. Facer, K., Joiner, R., Stanton, D., Reid, J., Hull, R., Kirk, D.: Savannah: mobile gaming and learning? J. Comput. Assist. Learn. 1980, 399-409 (2004)

39. Garcia, T., Pintrich, P.: Assessing students' motivation and learning strategies in the classroom context: the motivated strategies for learning questionnaire. In: Alternatives in Assessment of Achievements, Learning Processes and Prior Knowledge, pp 319-339. Springer (1996)

40. Garrison, D.R.: E-Learning in the 21st Century: A Framework for Research and Practice, 1st edn. Routledge, New York (2011)

41. Garrison, D.R., Archer, W.: A transactional perspective on teaching and learning: a framework for adult and higher education. Pergamon, Oxford (2000)

42. Garrison, D.R., Vaughan, N.: Blended learning in higher education. Jossey-Bass, San Fransisco (2008)

43. Gijsberts, M., Hujink, W., Dagevos, J.: Jaarrapport integratie 2011. Den Haag. http://prodb.gemeente.nu/PageFiles/23243/ 001_Jaarrapport_integratie_web.pdf (2012)

44. Gorges, J., Kandler, C.: Adults' learning motivation: expectancy of success, value, and the role of affective memories. Learn. Individ. Differ. 22(5), 610-617 (2012). doi:10.1016/j.lindif. 2011.09.016

45. Guay, F., Vallerand, R.J., Blanchard, C.: On the assessment of situational intrinsic and extrinsic motivation: the situational motivation scale (SIMS). Motiv. Emot. 24(3), 175-213 (2000)

46. Hansman, C.A.: Context-based adult learning. In: New Directions for Adult and Continuing Education 89, pp 43-51. JosseyBass (2001) 
47. Hill, L.H.: The Brain and consciousness: sources of information for understanding adult learning. In: New Directions for Adult and Continuing Education 89, pp 73-81. Jossey-Bass (2001)

48. Hoeymans, N., Timmermans, J.M., de Klerk, M.M.Y., de Boer, A.H., Deeg, D.J.H., Poppelaars, J.L., Thissen, F., Droogleever Fortuijn, J.C., de Hollander, A.E.M.: Gezond actief: de relatie tussen ziekten, beperkingen en maatschappelijke participatie onder Nederlandse ouderen (2005)

49. Houtkoop, W., Allen, J., Buisman, M., Fouarge, D., van der Velden, R.: Kernvaardigheden in Nederland: Resultaten van de Adult Literacy and Life Skills Survey (ALL). Expertisecentrum Beroepsonderwijs, Utrecht (2012)

50. Huang, H.M., Rauch, U., Liaw, S.S.: Investigating learners' attitudes toward virtual reality learning environments: based on a constructivist approach. Comput. Educ. 55(3), 1171-1182 (2010). doi:10.1016/j.compedu.2010.05.014

51. Illeris, K.: Towards a contemporary and comprehensive theory of learning. Int. J. Lifelong Educ. 22(4), 396-406 (2003). doi:10. 1080/02601370304837

52. Illeris, K.: Characteristics of adult learning. In: Adult Education-Adult Learning, Instruction and Program Planning, pp 36-41 (2010)

53. IUALL: Social conventions learning in mixed reality http:// www.commit-nl.nl/projects/wp-packages/social-conventionslearning-in-mixed-reality (2011)

54. Janssen, J., de Jong, J.G.M., Paulissen, R.T.: Mind Map Operational Demands \& Paper Prototype of Operational Demands Module in sCET. Soesterberg (2015)

55. Johnson, R.D., Hornik, S., Salas, E.: An empirical examination of factors contributing to the creation of successful e-learning environments. Int. J. Hum. Comput. Stud. 66(5), 356-369 (2008). doi:10.1016/j.ijhcs.2007.11.003

56. Jonassen, D.H.: Objectivism versus constructivism: do we need a new philosophical paradigm? Educ. Tech. Res. Dev. 39(3), 5-14 (1991)

57. Jonassen, D.H.: Thinking technology: toward a constructivist design model. Educ. Technol. 34(4), 34-37 (1994)

58. Jonassen, D.H., Davidson, M., Collins, M., Campbell, J., Haag, B.B.: Constructivism and computer-mediated communication in distance education. Am. J. Dist. Educ. 9(2), 7-26 (1995). doi:10. 1080/08923649509526885

59. Ke, F.: A case study of computer gaming for math: engaged learning from gameplay? Comput. Educ. 51(4), 1609-1620 (2008). doi:10.1016/j.compedu.2008.03.003

60. Ke, F., Xie, K.: Toward deep learning for adult students in online courses. Internet High. Educ. 12(3-4), 136-145 (2009). doi:10.1016/j.iheduc.2009.08.001

61. Kiili, K.: Digital game-based learning: towards an experiential gaming model. Internet High. Educ. 8(1), 13-24 (2005). doi:10. 1016/j.iheduc.2004.12.001

62. Kim, B.: Social constructivism. Emerg. Perspect. Learn. Teach. Technol. 1(1), 16 (2001)

63. Knowles, M.S.: Andragogy, not pedagogy. Adult Leadersh. 16(10), 350-352 (1968)

64. Knowles, M.S.: What is andragogy? In: The Modern Practice of Adult Education: From Pedagogy to Andragogy. Revised and updated, pp 40-59. Prentice Hall Regents, Englewood Cliffs (1970)

65. Knowles, M.S.: The Adult Learner: A Neglected Species. Gulf Publishing Company, Houston (1973)

66. Kolb, D.A.: Experiential learning: experience as the source of learning and development. Prentice-Hall Inc, Englewood Cliffs (1984)

67. Kolb, D.A., Boyatzis, R.E., Mainemelis, C.: Experiental learning theory: previous research and new directions. In: Sternberg,
R.J., Zhang, L.F. (eds.) Perspectives on Cognitive, Learning, and Thinking Styles. Lawrence Erlbaum, Mahwah (2000)

68. Kriz, W.C.: Creating effective learning environments and learning organizations through gaming simulation design. Simul. Gaming 34(4), 495-511 (2003). doi:10.1177/1046878103258201

69. Kurvers, J., Dalderop, K., Stockmann, W.: Cursistprofielen Laaggeletterdheid NT1 \& NT2. Tilburg (2013)

70. Kurvers, J., van de Craats, I.: Literacy and second language in the low countries. In: Young-Scholten, M. (ed.) Low-Educated Second Language and Literacy Acquisition Proceedings of the Third Annual Forum, pp. 17-23. Newcastle upon Tyne, England, Roundtuit Publishing, Durham (2007)

71. Lave, J., Wenger, E.: Situated Learning: Legitimate Peripheral Participation. Cambridge University Press, Cambridge (1991)

72. Levy, Y.: Comparing dropouts and persistence in e-learning courses. Comput. Educ. 48(2), 185-204 (2007). doi:10.1016/j. compedu.2004.12.004

73. Linnenbrink, E.A., Pintrich, P.R.: Motivation as an enabler for academic success. School Psychol. Rev. 31(3), 313-327 (2002)

74. Merriam, S.B.: Andragogy and self-directed learning: pillars of adult learning theory. In: New Directions for Adult and Continuing Education 89, pp 3-13. Jossey-Bass (2001)

75. Merriam, S.B.: Adult learning theory for the twenty-first century. New Dir. Adult Contin. Educ. 119, 93-99 (2008). doi:10. 1002/ace

76. Merriam, S.B.: Adult learning. In: Adult Education-Adult Learning, Instruction and Program Planning, pp 12-17. Elsevier Ltd (2010)

77. Mertens, H., van het Zwet, R.: Het versterken van de maatschappelijke participatie van oudere migranten. Utrecht (2009)

78. Mezirow, J.: Learning to think like an adult: core concepts of transformation theory. In: Jossey-Bass, S.F. (ed.) Learning as Transformation. Critical Perspectives on a Theory in Progress, pp 3-33 (2000)

79. Monahan, T., McArdle, G., Bertolotto, M.: Virtual reality for collaborative e-learning. Comput. Educ. 50(4), 1339-1353 (2008). doi:10.1016/j.compedu.2006.12.008

80. Muntean, C.I.: Raising engagement in e-learning through gamification. In: The 6th International Conference on Virtual Learning ICVL 2011, pp 323-329 (2011)

81. Murray, T.S., Kirsch, I.S., Jenkins, L.B.: Adult Literacy in OECD Countries: Technical Report on the First International Adult Literacy Survey (1997)

82. Neerincx, M.A., Lindenberg, J.: Situated cognitive engineering for complex task environments. In: Schraagen, J.M., Militello, L.G., Ormerod, T., Lipshitz, R. (eds.) Naturalistic Decision Making and Macrocognition, pp. 373-390. Ashgate Publishing Limited, Aldershot (2008)

83. Nielson, K.B.: Self-study with language learning software in the workplace: what happens? Lang. Learn. Technol. 15(3), 110-129 (2011)

84. OECD: Literacy in the Information Age: Final Report of the International Adult Literacy Survey (2000)

85. Pajares, F.: Self-efficacy beliefs in academic settings. Rev. Educ. Res. 66(4), 543-578 (1996)

86. Parker, A.: Identifying predictors of academic persistence in distance education. USDLA J. 17(1), 55-62 (2003)

87. Pauwels, G., Pickery, J.: Wie participeert niet? Ongelijke deelname aan het maatschappelijke leven in verschillende domeinen. SVR-Rapport 2007/5 (2007)

88. Peeters, M.: Personalized Educational Games-Developing Agent-supported Scenario-based Training (2014)

89. Peeters, M., Meyer, J.J.C., van den Bosch, K., Neerincx, M.A.: Situated cognitive engineering: the requirements and design of 
automatically directed scenario-based training. In: Proceedings of ACHI 2012: The Fifth International Conference on Advances in Computer-Human Interactions, pp 266-272 (2012)

90. Peeters, M., van den Bosch, K., Meyer, J.J.C., Neerincx, M.A.: Situated Cognitive Engineering: The Requirements and Design of Directed Scenario-Based Training (2012)

91. Petranek, C.: A maturation in experiential learning: principles of simulation and gaming. Simul. Gaming 25(4), 513-523 (1994)

92. Richards, C.: The design of effective ict-supported learning activities: exemplary models, changing requirements, and new possibilities. Lang. Learn. Technol. 9(1), 60-79 (2005)

93. Rieber, L.P.: Seriously considering play: designing interactive learning environments based on the blending of microworlds, simulations, and games. Educ. Tech. Res. Dev. 44(2), 43-58 (1996). doi:10.1007/BF02300540

94. Sansone, C., Smith, J.L., Thoman, D.B., MacNamara, A.: Regulating interest when learning online: potential motivation and performance trade-offs. Internet High. Educ. 15(3), 141-149 (2012). doi:10.1016/j.iheduc.2011.10.004

95. Scholz, U., Dona, B.G., Sud, S., Schwarzer, R.: Is general selfefficacy a universal construct? Eur. J. Psychol. Assess. 18(3), 242-251 (2002)

96. Schouten, D.G.M.: Improving Societal Participation for LowLiterates and Non-Natives Through Computer Support Tool Design (2013)

97. Schouten, D.G.M.: Computer-supported learning of societal participation skills by low-literates and non-natives. In: Proceedings of the 2014 European Conference on Cognitive Ergonomics, pp 1-2. ACM. http://dl.acm.org/citation.cfm?id= $2637282(2014)$

98. Schouten, D.G.M., Pfab, I., Cremers, A.H.M., van Dijk, B., Neerincx, M.A.: Gamification for low-literates: findings on motivation, user experience, and study design. In: Miesenberger, K., Fels, D., Archambault, D., Penáz, P., Zagler, W. (eds.) ICCHP 2014, Part I, LNCS 8547, pp. 494-501. Springer, Paris (2014). doi:10.1007/978-3-319-08596-8

99. Schunk, D.H.: Goal setting and self-efficacy during self-regulated learning. Educ. Psychol. 25, 71-86 (1990)

100. Schunk, D.H.: Self-efficacy and academic motivation. Educ. Psychol. 26(3\&4), 207-231 (1991)
101. Schunk, D.H.: Self-efficacy, motivation, and performance. J. Appl. Sport Psychol. 7(2), 112-137 (1995)

102. Schunk, D.H.: Self-efficacy for reading and writing: influence of modeling, goal setting, and self-evaluation. Read. Writ. Q. 19, 159-172 (2003)

103. Steehouder, P., Tijssen, M.: Opbrengsten in Beeld. Rapportage Aanvalsplan Laaggeletterdheid 2006-2010. Den Bosch (2011)

104. Teo, T.S.H., Lim, V.K.G., Lai, R.Y.C.: Intrinsic and extrinsic motivation in Internet usage. Omega: the. Int. J. Manag. Sci. 27, 25-37 (1999)

105. Thatcher, D.C.: Promoting learning through games and simulations. Simul. Gaming 21(3), 262-273 (1990)

106. Vacca, J.S.: Using scaffolding techniques to teach a social studies lesson about buddha to sixth graders. J. Adolesc. Adult Lit. 51(8), 652-658 (2008). doi:10.1598/JAAL.51.8.4

107. Van de Craats, I.: Obstacles on highway L2. In: Low-Educated Second Language and Literacy Acquisition: Research, Policy and Practice, pp 149-163 (2007)

108. Van Deursen, A.J.A.M., van Dijk, J.A.G.M.: Trendrapport Computer-en Internetgebruik 2011. Een Nederlands en Europees perspectief, Enschede (2011)

109. Van Linden, S., Cremers, A.H.M.: Cognitive abilities of functionally illiterate persons relevant to ICT use. In: ICCHP 2008, LNCS 5105, pp 705-712 (2008)

110. Van Oenen, G.: Liberaal denken, informaliteit en menselijke maat. Migrantenstudies 18(2), 93-99 (2002)

111. Verhelst, N., van Avermaet, P., Takala, S., Figueras, N., North, B.: Common European Framework of Reference for Languages: Learning, Teaching, Assessment. Cambridge University Press, Cambridge (2009)

112. Warren, S.J., Dondlinger, M.J., Barab, S.A.: A MUVE towards PBL writing: effects of a digital learning environment designed to improve elementary student writing. J. Res. Technol. Educ. 41(1), 113-140 (2008)

113. Wik, P., Hjalmarsson, A.: Embodied conversational agents in computer assisted language learning. Speech Commun. 51(10), 1024-1037 (2009). doi:10.1016/j.specom.2009.05.006

114. World Bank: Inclusion Matters: The Foundation for Shared Prosperity. World Bank, Washington (2013). doi:10.1596/978$1-4648-0010-8$ 